\title{
UNRWA AND THE PALESTINIAN REFUGEES: A HISTORY WITHIN HISTORY
}

\author{
Riccardo Bocco (Guest Editor)*
}

It is difficult to conceive a sustainable, long-lasting solution to the PalestinianIsraeli conflict without examining the refugee issue and identifying a just solution to it for both sides. Over time, and beside its emotional dimensions, the refugee issue has been increasingly regarded as a "problem" for the Israeli and the Palestine Liberation Organization (PLO)/Palestinian Authority (PA) leaderships, who have generally taken uncompromising positions. The international stakeholders have been unable to suggest compromises acceptable to the parties concerned. In a recent work, M. Chiller Glaus reviews in detail the juridical debates and the political proposals of the last twenty years and concludes that "there will be no Israeli-Palestinian Peace agreement if the question of refugees remains unresolved, and the question of Palestinian refugees will not be resolved without the concrete prospect for an overall Israeli-Palestinian agreement".

Sometimes depicted as "the original sin" of the Israeli State, ${ }^{2}$ the displacement of more than 700,000 Palestinian civilians during the 1948 war contradicts the Zionist myth of the right to "a land without people for a people without a land". Yet, for the Israeli population, the possible return of masses of Palestinian refugees is disconcerting as they view any such return as analogous to the effacement of Israel's Jewish character. ${ }^{3}$ Denying, ignoring or sweeping the refugee issue under the rug, therefore, has been the main approach of most Israeli governments since 1948 .

On the Palestinian side, and during the secret Oslo talks, the Fatah leadership accepted not to include United Nations General Assembly (UNGA) Resolution 194 of $1948^{4}$ in the Declaration of Principles, signed in

\footnotetext{
* Riccardo Bocco is a professor of Political Sociology at the Graduate Institute of International and Development Studies, University of Geneva.

1 See Michael Chiller Glaus, Tackling the Intractable. Palestinian Refugees and the Search for Middle East Peace, Bern, Peter Lang, 2007, 352.

2 See Dominique Vidal and Joseph Algazy, Le pêché originel d'Israël. L'expulsion des Palestiniens revisitée par les 'nouveaux historiens' israéliens, Paris, Editions de l'Atelier, 1998.

3 See the contribution of J. Peters and O. Gal in this volume.

4 Interpreted by the refugees as a legitimization of their right of return, paragraph 11 of this resolution resolves that: "the refugees wishing to return to their homes and live at peace with their neighbours should be permitted to do so at the earliest practicable date, and that compensation should be paid for the property of those choosing not to return and for loss of or damage to property which, under principles of international law or in equity, should be made good by the governments or the authorities responsible". See UNGA res. 194 (III), December 1948.
}

Refugee Survey Quarterly, Vol. 28, Nos 2 \& 3 C UNHCR [2010]. All rights reserved. For Permissions, please email: journals.permissions@oxfordjournals.org DOI:10.1093/rsq/hdq001 
September 1993, as a basis for negotiating a final peace agreement with the Israeli government. This decision sparked resentment and opposition among a majority of Palestinian refugees worldwide, who felt their right to return to their original homeland and/or their right to compensation had been betrayed. Although the Palestinian leadership has become progressively aware of the impossibility of return for millions of refugees, it has been seeking "principled" solutions related to at least a partial acknowledgement of responsibility by Israel. $^{5}$

As Rashid Khalidi has pointed out, "[a] combination of factors has prevented the negotiating process to be successful, including: callous pragmatism of US policy-makers, a balance of forces massively favourable to Israel (whose leaders would prefer to ignore both history and international legitimacy) and profound weaknesses in Palestinian negotiating performance from Oslo onwards". 6

Since the early 1990s, the United States of America and the European Union, in particular, have been advocating a realpolitik approach to the Palestinian refugee issue and have been pushing the Israeli and the Palestinian leadership to reach "hard compromises". While still awaiting positive developments, international donors have continued funding the United Nations Relief and Works Agency for Palestine Refugees in the Near East (UNRWA), which is commemorating its 60th anniversary in 2009 and is presently assisting nearly 4,700,000 people in the Near East. ${ }^{7}$

This introduction aims to provide a background to the contributions included in this special issue. In the first part, some short historical information on UNRWA and the Palestinian refugees helps to outline a number of characteristics of the two main actors under consideration. In the second part, some present challenges facing UNRWA and relevant future research topics are grouped in transversal themes that take into account the relationships between UNRWA and its clients.

\section{UNRWA}

\subsection{Ambiguities and strengths of the Agency's mandate}

The literature on UNRWA is relatively abundant. Besides the internal UNRWA reports, which contain important material on the evolution of the Agency's activities, as well as numerous evaluation and policy reports focusing on specific aspects of its work, one can find few analyses within social science research that

\footnotetext{
See the contribution of M. Dumper in this volume.

6 R. Khalidi, "Truth, justice and reconciliation: Elements of a solution to the Palestinian refugee issue", in Gh. Karmi and E. Cottran (eds.), The Palestinian Exodus, 1948-1998, London, Ithaca Press, 1999, 239.

7 See UNRWA, UNRWA figures as of 31 December 2008, Public Information Office, Gaza, March 2009.
} 
have focused on UNRWA. ${ }^{8}$ In this section, the main features of the Agency's mandate, role, and functioning are summarized.

UNRWA was created in the aftermath of the 1948 war and its mandate, as specified by UNGA Resolution 302(IV) of 8 December 1949, was twofold: to carry out, in collaboration with local governments, the direct relief and works programmes as recommended by the Economic Survey Mission and to consult with interested Near Eastern governments concerning measures to be taken in preparation for the cessation of international assistance for relief and works projects. ${ }^{9}$

UNRWA became operational in May 1950 and was created primarily to pursue emergency relief that had been carried out until December 1949 by the International Committee of the Red Cross (ICRC), the League of the Red Cross Societies (LRCS) and the American Friends Service Committee (AFSC); ${ }^{10}$ it was also tasked with the implementation of public works programmes aimed at the economic reintegration ${ }^{11}$ of Palestine refugees. The Agency has since become the only international organization set up to face a specific refugee problem in a specific geographical area (Gaza, West Bank, Jordan, Syria, and Lebanon). In principle, all other cases of forced migration are handled by the United Nations High Commissioner for Refugees (UNHCR), including Palestine refugees residing outside the UNRWA's five areas of operation. ${ }^{12}$

However, the Agency's mandate ${ }^{13}$ has been characterized from the beginning by a number of ambiguities related to the objectives of its donors and the possible impact of its operations, that is, the refugees' resettlement outside historic Palestine. This has cast doubts on the willingness of the international community to implement UNGA Resolution 194, which was considered by the Palestinian refugees as a guarantee of their right of return and/or compensation. By dissociating politics from humanitarian aid in the early 1950 s and through its Works programmes, UNRWA began implementing resettlement

8 Among the most important works, is worthwhile to mention: Edward Buehrig, The United Nations and the Palestinian Refugees, Bloomington, Indiana University Press, 1971, a work that has privileged a legal and international relations perspective. Milton Viorst, Reaching for the Olive Branch: UNRWA and Peace in the Middle East, Bloomington, Indiana University Press, 1989 and "Palestinian Refugees and non-Refugees in the West Bank and the Gaza Strip", Special Issue of Journal of Refugee Studies, 2(1) 1989, both published on the 40th anniversary of the Agency. Benjamin N. Schiff, Refugees into the Third Generation. UN Aid to the Palestinians, Syracuse University Press, 1995, which is to date probably the most thorough account of UNRWA in a political economy perspective. Finally, the more recent work of Robert Bowker (Palestinian Refugees. Mythology, Identity and the Search for Peace, Boulder, Lynne Rienner Publishers, 2003) is a very interesting account of the Agency by a former Australian ambassador in the Middle East and senior official of UNRWA in Gaza and Jerusalem.

9 UNGA res. 302 (IV), 8 Dec. 1949, para. 7.

10 While the AFSC, the Quakers' organization, had been active mainly in Gaza, the ICRC and the LRCS had been catering to the needs of the displaced in the West Bank, Jordan, Syria and Lebanon.

11 The term "reintegration" was meant to include both the notions of "repatriation" and "resettlement".

12 For an example of refugees residing outside UNRWA's areas of operation, see the contribution of O. Al Abed in this volume on the critical situation of the Palestinians in Egypt.

13 On the evolution of UNRWA's mandate, see the contribution of L. Bartholomeusz in this volume. 
strategies, the scope of which was humanitarian (rather than political) but with political consequences.

Furthermore, UNRWA has not been responsible for the search for a durable solution, as this task was officially devolved to the United Nations Conciliation Commission for Palestine. Officially a non-political organization, UNRWA has been deeply involved in a highly politicized context from the beginning. Though in its practical endeavours UNRWA has been solution-oriented, "finding solutions" could conflict with its stated objectives. What made and makes UNRWA's actions in the region successful are their ambiguities and the Agency's capacity to manage these ambiguities at the same time. Three examples - (a) implementation of its mandate, (b) finances, and (c) duration - help to explain the situation.

(a) The Agency was never provided with a specific statute or charter other than the recommendations outlined in the Economic Survey Mission's Report. ${ }^{14}$ In the same vein, the UNGA has offered little guidance concerning the evolution of UNRWA's mandate. ${ }^{15}$ On the one hand, this has proven problematic because the Agency's top management has had to take critical decisions due to the changing environment in which it operates. On the other hand, the Agency's broad mandate has led to positive adaptation and innovation.

- After the political opposition to the implementation of its large-scale work programmes in the mid-1950s, UNRWA turned to the provision of "essential services" (primary health care, relief, and social services) and focused on education. This concentration of activities on human development also contributed indirectly to the protection of Palestine refugees and their legitimate cause, without jeopardizing the right to return. From the 1960 s onwards, education has become the largest single programme in terms of investment, funding, and personnel involved. The works (development) programmes resumed in a different manner only in the second half of the 1980s, mainly in the West Bank and the Gaza Strip.

- Though UNRWA, unlike UNHCR, does not have a clearly stated protection mandate, it has taken a number of initiatives in this direction. This was particularly the case with the creation of Refugee Affairs' Officers during the first Intifada in the West Bank and

14 Headed by G. Clapp, former director of the Tennessee Valley Authority, the Economic Survey Mission (ESM) never envisaged studying plans of repatriation because of their political character. The ESM recommendations are also a good example of the economic development approach fostered by the United States in the early 1950s and the attempt to transfer to the Middle East a successful model applied in the mid-West of the United States. See also the pioneering work of Paul W.T. Kingston (Britain and the Politics of Modernization in the Middle East 1945-1958, Cambridge University Press, 1996) detailing the diverging development strategies pursued by the British and the (American) Point IV administration in the Middle East during the 1950 s.

15 During the 1950s and part of the Cold War era, the main interest of Western donor countries through UNRWA's socio-economic assistance was to insure political stability in the region and to prevent the spread of communist ideology among refugee communities. 
Gaza. Besides the ethical position of its management, this example demonstrates the possibility for the Agency to interpret its mandate from a protection perspective within delicate political contexts. $^{16}$

(b) The funding system is another factor showing the fragility and the dependency of the Agency. The funding, in fact, is guaranteed only by the voluntary contributions of donor countries. This means that the lack of a self-generated financial base or a United Nations assessment-based contribution system has historically set limits to UNRWA's initiatives, activities, and autonomy from donor countries' political interests. Yet, at the same time, constant fluctuations in financial support clearly show the (in)coherence of donor policies in different periods and at several levels (importance of bilateral versus multilateral cooperation; changing of political stands according to realpolitik or sticking to positions of principle; shifting international political alliances during and after the Cold War). In this sense, the financial crisis of the second half of the 1990s has not been a new episode in the history of UNRWA but rather a recurrent one. As a consequence, the Agency has had to develop communication skills to market its mission and to secure funding.

Though UNRWA has often been successful in fundraising, the 1990s proved particularly difficult. Notwithstanding the initial euphoria for the peace process and its progressive setbacks (both processes potentially favourable for fundraising), the post-Cold War period has been characterized by an increased need for humanitarian assistance in different regions of the planet and, at the same time, the triumph of neoliberal policies that have set serious limits on the public expenditures of donor countries.

(c) A final paradox is the fact that UNRWA is considered to be temporary but its mandate has been renewed every three years and the Agency has now been in existence for more than half a century. One can certainly argue that the precariousness of UNRWA's funding system or the ambiguities of its mandate are basically linked to the fact that the Agency was meant to be dissolved within a few years after its establishment. In this sense, by successfully serving a steadily growing Palestine refugee community, UNRWA has become both a hopeful sign that a just settlement of the refugee issue based on international law is possible and the symbol of the failure of the international community to solve the Palestine question.

16 The contribution of B. Goddard in this volume gives a historical perspective and a comparative juridical analysis of UNHCR and UNRWA's mandates. The contributions of M. Kagan and N. Morris point at future perspectives for the Agency's role in refugee protection. 


\subsection{The "Blue State": UNRWA as a post-colonial globalized bureaucracy}

If we look at the Agency's personnel and activities, the figures are impressive. ${ }^{17}$ At the end of the first decade of the new century, UNRWA employs almost 30,000 people, caters to the needs of almost 4,700,000 registered refugees, and provides services in fifty-eight camps scattered in its five fields of operation. The Agency runs 689 schools and 10 vocational and technical training centres, attended by almost half a million students, with an educational staff of more than 21,200. One-hundred and thirty-eight Primary Health Care Facilities administered by almost 4,200 medical staff received more than 9.5 million patient visits in 2008. In the Relief and Social Services' sector, 700 staff members assist more than 257,000 special hardship cases (6 per cent of total registered refugees) and supervise sixty-five Women's Programme Centres and thirty-seven Community Rehabilitation Centres. The Microfinance and Microenterprise Department has awarded (since 1991-92) more than 165,000 loans with a cumulative value of almost 182 million US dollars.

The figures above reveal the quasi-state function of UNRWA constituting a parallel public service provider (to alleviate the financial burden on host countries) and a "non-territorial administration" without coercive power, which has to achieve its objectives mainly through mediation. Nonetheless, the role and activities of the Agency - often labelled the "Blue State" (because of the United Nations flag) - at times have cast doubt on the legitimacy of UNRWA's presence in some host countries, including Jordan in the late 1960s and early 1970s and Lebanon from the late 1970s.

The example of the Hashemite Kingdom during the 1990s sheds light on how UNRWA can become trapped in a situation of potential hostility towards its role by part of the population of a host country. Starting from 1989, the Jordanian government engaged in political liberalization, driven largely by the structural adjustment programme imposed by the Bretton Wood's institutions. The economic hardship of the country was aggravated by the government's stance during the 1990-91 Gulf War and the influx of almost 300,000 returnees, the majority of whom were Jordanian passport holders of Palestinian origin, ${ }^{18}$ along with an approximately similar number of Iraqi asylum-seekers.

After the civil war of the early 1970s and during the 1980s, the country managed to attain a certain level of political and economic stability. Besides infrastructure development, the government was able to expand public employment and favour its allies in the private sector. The urban centres - where a majority of the Jordanian population of Palestinian origin resided - were the main beneficiaries of state resource allocation. However, this policy was partly to

17 See: UNRWA, UNRWA figures as of 31 December 2008, Public Information Office, Gaza, March 2009.

18

On the domestic level and to face economic hardship, the government was bound to negotiate a new 'social
pact' with its subjects to avoid political unrest. Actually, in the early 1990s, the external rent derived from
international aid (Arab and Western) and Jordanian migrant workers' remittances had seriously dried up. 
the detriment of the rural areas of the kingdom, whose inhabitants - the traditional "Transjordanian" backbone of the monarchy - did not fully benefit from the period of socio-economic development.

During the 1990s, two main processes influenced each other. On the one side, internal political liberalization policies took shape with the signing of a new "National Charter", the lifting of Martial Law, the reintroduction of parliamentary elections and of political parties, as well as the proliferation of non-governmental organizations (NGOs). On the other side, the Peace Process led to the Aqaba Treaty of 1994 and to hopes for a peace dividend as well as to increased interaction among Israeli and Palestinian elites. Most importantly, the Peace Process reawakened some of the "old ghosts", in particular the view that a possible peace option would lead to the final resettlement of Palestinian refugees in the kingdom.

Political liberalization and the Peace Process influenced each other both at the domestic and international levels. Successive periods of stalemate in the peace negotiations fostered the growth of an "anti-normalization front", signalling a situation of "cold peace" - peace between the elites but not yet between societies. The fear of a Watan al-badil ${ }^{19}$ option for the Palestinians of the Kingdom stimulated the re-emergence of a Transjordanian nationalist project.

In the Hashemite Kingdom, most Palestinian refugees have a Jordanian passport. They are part of a complex Palestinian exile community. Less than 20 per cent of UNRWA-registered refugees are camp residents and, during the 1970-80s, many refugees experienced socio-economic development. Though a debate has raged over discrimination towards Jordanians of Palestinian origin, they constituted one-half of the kingdom's middle class. ${ }^{20}$ Notwithstanding the financial difficulties of UNRWA and the cuts in a number of sectors, the Agency still represented a form of welfare state for most registered refugees and for the less economically favoured among them, in particular, in the 1990s. This was in marked contrast with the situation of the less privileged fringes of Jordanian society, who were suffering from structural adjustment programmes. UNRWA's continued assistance began to be interpreted as a bias of international donor support for one sector of the host country population. This presumed bias was used by Transjordanian nationalists to support anti-regime propaganda, to oppose the Peace Process, and to fuel anti-Palestinian feelings. ${ }^{21}$

19 This literally means a "swap of national home and/or national belonging" and the end of irredentism for the Jordanians of Palestinian origin. The "ethno-national" question was but one face of the coin. The other was the emergence of new forms of social inequalities and divisions, mainly produced by the externally fostered economic reforms and cutting across geographical areas of residence in the Kingdom, political ideologies and affiliations.

20 Furthermore, Jordan has hosted and hosts important groups of the Palestinian elite. Socially speaking, intermarriage between Jordanians and Palestinians has become a widespread practice; politically, most Jordanians of Palestinian origin have been socialized in the kingdom; economically, they have shared in the country's system.

21 For the political domestic changes in Jordan during the 1990s, the resurgence of the Transjordanian nationalist movement and the effects of the Peace process, see: A. Abou Odeh, Jordanians, Palestinians and the Hashemite Kingdom in the Middle East Peace Process, Washington, United States Institute of Peace 
If we turn to UNRWA staff, more than 99 per cent of the personnel have historically been recruited among Palestinian refugees and host country nationals. This has often been considered an advantage for the Agency, in comparison with other humanitarian organizations, in that the efficiency and efficacy of its assistance in times of crisis can partly be explained by the intimate relationships between its civil servants and the beneficiary population. In this sense, UNRWA also represents a microcosm of Palestinian society; the Agency's archives are considered to be part of Palestinian national heritage and an extremely important historical resource. The history of UNRWA and the history of Palestinian refugees are, thus, inseparable: the latter is an indispensable element in understanding the former and vice versa. ${ }^{22}$ As $\mathrm{R}$. Bowker has suggested, " $\left.\mathrm{t}\right] \mathrm{he}$ political mythologies and memories of Palestinian refugees in which UNRWA is deeply embedded [...] are central elements in Palestinian politics. Palestinian refugees, whose education and health services are provided by UNRWA, are not merely recipients of international aid. Viewed in terms of the historical conflict between Palestinians and Israelis, the relationship of the refugees to UNRWA has been instrumental in forging their sense of identity as refugees, their claims for justice, and their perceptions of the roles and responsibilities of other parties relevant to their situation and aspirations". ${ }^{23}$

Finally, one cannot overlook the fact that, for many decades, UNRWA's top management posts have been filled by internationals (most often of North American or European origin), whose professional experience has been grounded in the diplomatic, development, humanitarian, or human rights fields. ${ }^{24}$ From the late 1960s until the mid-1990s, a stable group of long-time international employees headed the Agency, with a high level of bureaucratic centralization. ${ }^{25}$ Some observers have been tempted to portray UNRWA as a colonial administration, but such critics forget that having international managers has been an

Press, 1999; R. Storaci, Le dinamiche palestinesi nella politica giordana. Prospettive per la stabilità di un Pivotal State, Roma, Centro Militare di Studi Strategici, 2002; A. Susser, Jordan. Case-study of a Pivotal State, Washington, The Washington Institute for Near East Policy, 2002.

22 See the contribution of R. Farah in this volume.

23 R. Bowker, 2003, op. cit., 2.

24 During the first two decades of its existence, an important number of the Agency's international staff were former military and colonial administrations' civil servants, mainly from the UK and the United States. For several decades, UNRWA's bureaucratic culture has been shaped in relative isolation from the other United Nations sister organizations, the most notable exception being the United Nations Educational, Scientific and Cultural Organization (UNESCO) and the World Health Organization (WHO) whose cooperation with UNRWA in the education and health sectors dates to the late 1950s. The last decade has witnessed important changes, in particular in terms of staff secondment from other United Nations agencies, the UNHCR seemingly playing a pivotal role for the replacement of a number of directors at the field and HQ levels. During the mandate of the present Commissioner-General, Karin Abu Zayd, and under increased pressure from a number of international donors, UNRWA has been innovative, exploring new forms of management and external collaborations in its different sectors of activity.

25 It is important to remember that UNRWA Headquarters were originally based in Beirut then split between Amman and Vienna after the beginning of the Lebanese civil war. In 1996, following the start of the Palestinian autonomy in Gaza, the then new Commissioner-General, Peter Hansen, decided to relocate the Vienna offices back to the region. It is during this move that the Agency "lost" most of its professional old staff. Currently, the headquarters is divided between Amman, Gaza and Jerusalem. 
essential way of preserving the Agency's independence from undue influence by different Palestinian political factions. Once again, in the past two decades, the Agency has been able to turn this possible source of ambiguity into a positive force. Starting at the end of the 1980s and, in particular, after the beginning of the Peace Process, an increasing number of Palestinian staff have been promoted to higher ranks, in view of preparing the hand-over of the Agency's administrative responsibilities. On the other side, an increasing number of junior international staff members have been seconded to UNRWA through cooperation agreements in its different fields of operation.

\section{Palestinian Refugees ${ }^{26}$}

\subsection{Defining and counting refugees}

In looking at who is a Palestinian refugee, there is no definitive response. The definition and the number of Palestinian refugees can differ according to the approach (administrative, juridical, political) used to define Palestinian refugees and also according to the social context of interaction between Palestinians (registered refugees or not) and others and the actors defining them.

UNRWA, particularly at the beginning of its mandate, lacked a fixed definition; this changed mainly due to a need to delimit the number of relief recipients. When the Agency began its activities, it inherited a legacy of inflated registration: the United Nations Economic Survey Mission recorded approximately 720,000 people, while the number of recipients on the ration rolls of the United Nations Relief for Palestine Refugees (UNRPR) surpassed 950,000. It is the 1952 definition that has become the accepted one and has remained virtually unchanged: "a Palestine refugee shall mean any person whose normal place of residence was Palestine during the period June 1, 1946 to May 15, 1948, and who lost both home and means of livelihood as a result of the 1948 conflict". ${ }^{27}$

Some remarks should be noted. Firstly, those refugees who were "not in need" or who fled outside the UNRWA areas of operation were not registered. Secondly, the descendants of original registered refugees inherited UNRWA's administrative title independently of the fact that they may have obtained a nationality and/or left the Agency's fields of operation. Thirdly, UNRWA inherited (from its predecessors and prevailing host country policies at the time) some degree of gender discrimination in the implementation of its definition; a registered refugee woman marrying a non-refugee, for example, would lose her

26 The term "Palestine" in the acronym of the United Nations Agency refers to the areas formerly under British Mandate (also known as "historic Palestine"), which included the Gaza Strip, the West Bank and the territories that became the State of Israel. Until 1952, UNRWA catered also to the needs of the Jewish communities displaced during the 1948 war. In this paper, the term "Palestinian refugees" mainly refers to the Arab population of Palestine displaced during the 1948 conflict.

27 For full details of eligibility instructions, see in the Appendixes to this volume: UNRWA. Consolidated Eligibility and Registration Instructions (CERI), 2006. See also: L. Takkenberg, The Status of Palestinian Refugees in International Law, Oxford, Clarendon Press, 1998, ch. 2. 
status (although she could reclaim it in the event of divorce or widowhood) whereas a refugee man marrying a non-refugee would retain his status.

It is important to emphasize that the UNRWA definition of a Palestine refugee is an administrative one and does not translate directly into recognition by international law. Furthermore, a tacit understanding seems to prevail: UNRWA's continued existence (and the associated Palestine refugee status) is directly linked to the realization of a permanent resolution to the Palestine refugee issue.

In terms of current figures (and according to the UNRWA definition), registered refugees total nearly 4,700,000 people from three generations. As for their geographical distribution, nearly 42 per cent live in Jordan, 23 per cent in Gaza, 16 per cent in the West Bank, 9 per cent in Lebanon, and 10 per cent in Syria. An average of slightly less than 30 per cent of the registered refugees are camp residents - the most important exceptions being Lebanon and Gaza with 53 and 46 per cent, respectively. ${ }^{28}$ Gaza is also the field in which registered refugees constitute more than 70 per cent of the total resident Palestinian population, while in Jordan their number accounts for almost one-third of the Hashemite Kingdom population.

However, the administrative definition of a Palestinian refugee adopted by UNRWA does not correspond with the political definition of Palestinian refugees and displaced Palestinians. It differs, for example, with the definition noted in the statement of the Palestinian delegation at the first meeting of the Refugee Working Group, held in Canada in May 1992, and also in official PLO publications. $^{29}$ Different definitions generate different figures. According to the UNRWA definition, less than 50 per cent of an estimated 10.5 million Palestinians worldwide are refugees while, according to a political definition, their number is closer to two-thirds of the total. Whether defined administratively or politically, the refugees nevertheless constitute the bulk of the Palestinian diaspora. If we consider the social definition (self-definition) of most Palestinians, the figure could be even higher.

The issue of definition is central to the peace negotiations because of its political consequences, in terms of demography and in relation to UNGA Resolution 194. However, the reality of Palestinian refugees today cannot be read exclusively in juridical terms; their socio-political and symbolic relevance goes well beyond. They have both been symbols of the Palestinian plight and among the main craftsmen of the Palestinian National Movement (PNM).

\footnotetext{
28 See: UNRWA, UNRWA figures as of 31 December 2008, Public Information Office, Gaza, March 2009.

29 See: S. Tamari, Palestinian Refugee Negotiations. From Madrid to Oslo II, Washington, Institute of Palestine Studies, 1996; and PLO, The Palestinian Refugees Factfile, Jerusalem/Ramallah, Department of Refugee Affairs, April 2000. It should also be noted that, in Arabic, Palestinians refer to the 1948 refugees and their descendants as lajiun, while the term nazihîn is used for the 1967 displaced along with their descendants. In the latter case, the two categories can overlap because an important number of refugees were displaced a second time during the 1967 war.
} 


\subsection{The Refugees as a symbol and as victims of the quest for Palestinian independence: from the Nakba to the Oslo Process 30}

If we look at the regional context, in the wake of the First World War and the dissolution of the Ottoman Empire, the creation of new states under the British and French Mandate cut across socio-political formations and prevented the implementation of pan-Arab national aspirations. Palestinians were the sole group that was not endowed with a territorial state at the time of independence. While, from the late 1940s onwards, most Arab-independent states worked to forge new national identities (sometimes in competition with pan-Arab political ideals), the Palestinians progressively built up their national movement in exile. In other words, while in most Arab countries state-building preceded nation-building, it happened the other way round for the Palestinians and, in this context, refugees played a key-role. Without embarking upon a larger analysis of the PNM, it is important to recall the indirect contribution of UNRWA to its development and some of the attempts of the PNM to make use of the Agency through the refugees. In this sense, one can wonder how an operational agency can manage to avoid identifying with the cause of those it serves. For UNRWA, the issue has been made even more delicate by virtue of the fact that most of its personnel are recruited from among the refugee population itself.

After the Nakba, most registered refugees and, in particular, camp residents were Palestinians of rural origins (peasants and Bedouins). Through its humanitarian aid and relief activities, UNRWA offered the space and the means to reconstitute in exile the fabric of Palestinian society, its networks of solidarity, and, in part, its traditional local authorities (mukhtars and village shaykhs). In the 1950s, many Palestinian political activists were teachers who directly and indirectly used UNRWA schools to mould a new generation of young refugees. With the creation of the PLO in 1964, the context of UNRWA's action became marked by the existence of an explicit national project, the objectives of which were confined not only to the implementation of the right of return but also to the liberation of Palestine, the institutionalization of a national identity, and the creation of an independent state.

Starting in the second half of the 1960s, UNRWA was even more clearly targeted, both as the symbol of the refusal of refugee resettlement and as a space for the reproduction of a specific Palestinian identity. The PLO tried to use UNRWA infrastructure and services, as much as possible, to strengthen the

30 Many relevant scientific contributions on the Palestinian refugee issue, written by Palestinian, Israeli and international researchers, can be found in Journal of Palestine Studies (Washington) and Etudes Palestiniennes (Paris) published by the Institute of Palestine Studies (IPS). See also: Elia Zureik, Palestinian Refugees and the Peace Process, Washington, IPS, 1996; and Salim Tamari and Elia Zureik (eds.), Reinterpreting the Historical Record: The Uses of Palestinian Refugee Archives for Social Science Research and Policy Analysis, Jerusalem, Institute of Jerusalem Studies, 2001. Some of the published and most of the unpublished literature related to the refugee negotiations is available on the Palestinian Refugee ResearchNet, also known as FOFOGNET (http://prrn.mcgill.ca/uptodate/uptopdate_fofognet.htm) (last visited 20th September 2009), originally established to link members of a Canadian academic advisory group to the gavel-holder of the Refugee Working Group of the multilateral Middle East Peace Process in the early 1990s. 
ideological and material support for the PNM among refugees. Predictably, this caused problems for UNRWA, creating conflicts within the Agency and with host countries. In most cases, refugee camps became operational bases for political activism and, in some cases like Lebanon, camps and schools were also used as paramilitary bases.

Official relations between the PLO and UNRWA were established only in 1975, after formal recognition of the PLO by the UNGA. These changes led to increased legitimacy for the PLO as the representative and protector of refugees, locally, regionally, and internationally. From the mid-1970s onwards, the PLO tried to use UNRWA for its own purposes - to influence educational policies and professional training in particular - but with limited success. The PLO's success remained limited even after it helped the Agency to fundraise among Arab donors, especially after the Baghdad Summit of 1978 and the creation of the Joint Jordanian Palestinian Fund (JPPC) the initial assistance of which targeted non-refugee populations. Beginning in 1986, in Gaza, UNRWA became a privileged instrument for the PLO's "steadfastness strategy". The funds received by UNRWA through the JJPC were mainly used to develop infrastructure in the camps and to offer local employment, partly as a way of curtailing the Palestinian workforce's dependence on the Israeli labour market. Notwithstanding episodes of collusion between the Agency and the PLO in fundraising, UNRWA was able to keep its distance from the PLO's influence. This clearly signalled that decision-making in UNRWA was firmly in the hands of its (international) top management and indirectly controlled by its (Western) donors.

In the wake of the 1990-91 Gulf War, the Palestinians were denied an official independent representation at the Madrid Peace Conference. Their leadership was weakened by the loss of the financial support traditionally granted by the Arab states and by the loss of migrant worker remittances from the Gulf. Although the PLO had managed to build up a Unified Command in the Occupied Territories, the Intifada did not seem to be bearing fruits. It was in a highly unbalanced power relationship that the Palestinian leadership secretly negotiated the Oslo Accords.

Following the signature of the "Declaration of Principles" in Washington DC (September 1993) and the "Gaza and Jericho first" Accords in Cairo (May 1994), Y. Arafat officially entered the Autonomous Territories in July 1994, marking the presence of a new Palestinian National Authority. Endowed with one element of statehood, for the past fourteen years, the Palestinians have not yet been able to reach a final agreement on the precise size of the territory and the population over which their National Authority can exert its power. The Interim Agreement of September 1995 was meant to define the calendar and the conditions of Palestinian autonomy. However, the size and boundaries of Palestinian territory and the question regarding who is entitled to become citizens of any new state are still key questions awaiting answers.

In the wake of the peace agreements, several splits began to materialize among Palestinians, especially among residents in the West Bank and Gaza. The most visible of these splits have been those between the "Palestinian of 
the interior" and the "returnees" or, more dramatically, between the detractors of the Oslo Accords (the Islamic movements and their allies) on the one side, and the PA and Fatah on the other side. The peace process not only signalled a clear danger for national unity but it also led to a vicious cycle of escalation of violence and massive counter-measures (both from outside and inside Palestinian society). In the 1990s, the "land for peace" deal shifted progressively towards a "security for peace deal". For the average Palestinian, peace has meant a new situation of latent fight: the old enemy has not disappeared from daily life; movement remains strictly controlled; and land confiscation and house demolitions continue.

By mid-2000, real per capita GNP of the Palestinian national economy had declined by 20 per cent since the beginning of the Oslo process, despite over 3 billion US dollars in foreign aid. Per capita consumption had declined by 15 per cent, reflecting increased poverty, and core unemployment rates had tripled. A functioning Palestinian national economy continued to be a dream, insofar as the Paris Agreement of 1994 had consolidated Palestinian dependence on Israel. ${ }^{31}$

The refugees in the Autonomous Territories quickly found themselves in a critical situation and were drawn to take radical positions. The Oslo Accords had created a division among 1948 and 1967 refugees by seemingly limiting the right of return. Palestinians as a stateless nation began to witness the formation of nationless state. In trying to organize across borders and to obtain fair political representation, most refugee communities felt deeply frustrated, disenchanted, and anxious over their future. Refugees feared becoming second-class citizens, since priority had been given to the returnees ( $a^{\prime} i d \hat{u} n$ ) or to those complying with the regime's project. $^{32}$ Refugees also felt that the PA, preoccupied with statebuilding, was possibly too eager to compromise in a final status negotiation. Because of their experience, they were not confident that the international community would or could support their cause.

\subsection{The political representation of the refugees: a key issue at stake}

After the Oslo Agreements, the perception that the Palestinian Authority was too strongly involved in a process of statebuilding and less worried about negotiating the implementation of UNGA Resolution 194 mobilized the refugees. The project of Palestinian national construction built in exile and in the diaspora seemed endangered by the peace process. Hypotheses related to a gradual transfer of refugee assistance programmes from UNRWA to the PA were strongly opposed by several refugee camp committees who feared losing their right of return. With the "autonomous areas" becoming equivalent to those of other host

31 See Nigel Roberts, "Hard lessons from Oslo: foreign aid and the mistakes of the 1990s" , M. Keating, A. Le More and R. Lowe (eds.), Aid, Diplomacy and Facts on the Ground, London, Royal Institute of International Affairs, 2005, 17-26.

32 For a more recent analysis of the issue, see: Benoit Challand, "Les mutations du leadership palestinien (19932007)", A contrario, 5(2) 2008, 52-75. 
countries, UNRWA developed official relationships with the PA although they were mostly limited to technical cooperation.

The question of refugee representation has not been included in UNRWA's mandate. It is a problematic issue because of its sensitivity at different levels, both inside and outside the West Bank and Gaza. Inside, it is problematic because it questions the role and legitimacy of independent NGOs or PA institutions. Outside, it is problematic because it can clash with the domestic affairs of Arab host countries ${ }^{33}$ and with the official role of the PLO as well. In all cases, raising the issue can also be perceived as an intrusion by Western donors or regional stakeholders.

It was during the 1990s (following the Abu Mazen and Beilin proposal of 1995 which included a solution to the refugee issue $)^{34}$ that the BADIL Resource Center for Palestinian Residency and Refugee Rights, a NGO based in Bethlehem, began focusing on a rights-based approach to the refugee question. ${ }^{35}$ BADIL began questioning the representative role of the PA in negotiating the future of the refugees and their right of return in particular. The BADIL stance and initiatives quickly spread outside the West Bank and Gaza, to the region and beyond. ${ }^{36}$ Second- and third-generation descendants of 1948 refugees and Palestinian residents in North America were instrumental in federating local associations around the world to create al-Awda ("the return" in Arabic), a new NGO lobbying and advocating for Palestinian refugee rights. ${ }^{37}$

The Camp David Summit of July 2000, chaired by President Clinton and hosting the Israeli and Palestinian delegations (headed respectively by E. Barak and Y. Arafat), probably constitute a watershed in the refugee negotiations. The secret Stockholm talks of the spring of the same year had not born fruit and the PA was reluctant to engage in final status negotiations, but Clinton was approaching the end of his mandate. The summit took place amidst strong pressure from Palestinians at home and from refugee organizations worldwide. Arafat tried unsuccessfully to negotiate Israeli recognition of the right of return and acknowledgement of (partial) responsibility for having created the problem. The talks failed but accelerated the pace of bilateral negotiations which, following the Clinton Parameters of December 2000, reached a promising peak in

33 For Palestinians in the diaspora, being the holder of another citizenship may be conflicting. After Black September, in Jordan there has been a tacit agreement that Palestinians would not raise the issue of representation.

34 Beside detailed mechanisms for rehabilitating and compensating refugees aimed at rendering return less attractive, the agreement stipulated no official limitation for immigration in Palestine but no refugee return to Israel. See: http://www.mideastweb.org/beilinabumazen1.htm.

35 BADIL Resource Center for Palestinian Residency and Refugee Rights was officially established in January 1998. See: http://www.badil.org (last visited 15th September 2009).

36 See in particular the contributions of Susan Akram and Ingrid Gassner Jaradat in Naseer Aruri (ed.), The Palestinian Refugees. The Right of Return, London, Pluto Press, 2001.

37 Al 'Awda. The Palestine Right to Return Coalition, founded in April 2000 in New York has several branches in North America, Europe and Palestine with a network of related associations. See: http://www.al-awda.org (last visited 15th September 2009). 
Taba in January 2001. ${ }^{38}$ Though the Second Intifada had already erupted by late September 2000, the Taba meetings signify the closest point at which the negotiators of both parties came to a political solution to date. The election of Ariel Sharon as Prime Minister and the stance of the new United States President subsequently ushered in a new era.

Since the beginning of the al-Aqsa Intifada, the living conditions of the Palestinian civilian population (refugees included) have been steadily deteriorating at all levels. This period saw the death of Arafat in 2004, the victory of Hamas in the 2006 elections (followed by an international boycott), and the seizure of power by the Islamic Resistance Movement in Gaza in 2007, which marked a fatal breakdown of national unity with the Fatah. ${ }^{39}$ UNRWA as well as many other humanitarian organizations operating in the Autonomous Territories has become hostages of the situation, playing the role of fig leaves, and hiding the reality of the situation from international decision-makers incapable of finding an adequate political answer to the conflict. ${ }^{40}$

The ongoing crisis began in the fall of 2000, with peaks of violence and temporary truces as well as second-track negotiations, each of them including proposals on the refugee issue. ${ }^{41}$ Academics, policy makers and local and international political figures have strived to develop proposals to resolve the decades-long conflict. What has characterized most shadow negotiations has been the absence of refugee representatives with legitimate mandates from their communities, in particular those living in the Gaza and West Bank camps. $^{42}$

In fact, official representatives of Palestinian refugees have rarely been involved in the negotiations concerning their future status. During the Oslo years and thereafter, the PLO/PA leadership has often seemed to perceive them more as obstacles and threats rather than as potential key partners or actors with insight crucial to the debate and negotiations. Altering this approach could have helped counter the sense of distrust and opposition felt by many

38 Jalal Al-Husseini and Riccardo Bocco, "Les négociations israélo-palestiniennes de juillet 2000 à Camp David : reflets du Processus d'Oslo", Relations Internationales, no. 136, hiver 2008, 51-72.

39 Besides the regular OCHA reports available on the website of the United Nations Agency (http://www .ochaopt.org) (last visited 16th September 2009), see: UNCTAD, The Palestinian War-Torn Economy: Aid, Development and State Formation, Geneva, UNCTAD/GDS/APP, 2006.

40 See the Report of the United Nations Special Coordinator for the Middle East Peace Process: Alvaro De Soto, End of Mission Report, May 2007; Anne Le More, International Assistance to the Palestinian After Oslo. Political Guilt, Wasted Money, London, Routledge, 2008; and Riccardo Bocco et Wassila Mansouri, "Aide internationale et processus de paix : le cas palestinien (1994-2006)", in : R. Bocco and D. Meier (eds.), La Palestine et les conflits du Moyen-Orient, special issue of A contrario, 5(2) 2008, 6-22.

41 M. Chiller Glaus (2007, op. cit.) gives a thourough account of all the plans: from the Abu Sitta's and the Citizenship/Residency Approach, to the Geneva Initiative, including the H. Agha and R. Malley proposal for return into swapped areas, the Y. Peled and N. Rouhana's transitional justice approach, the Gush Shalom or the Ayalon-Nusseibeh's proposal, and the bi-national State project. See also the contribution of M. Dumper in this volume.

42 Concerning the recent evolutions of the Palestinian internal debate on the right of return, see: Jalal AlHusseini, "Visions palestiniennes du Droit au retour sept ans après le début de la seconde Intifada (20002007)”, R. Bocco \& D. Meier (eds.), La Palestine et les conflits du Moyen-Orient, special issue of A contrario, 5(2) 2008, 37-51. 
Palestinian refugees and, instead, garnered their support paving the way to new dynamics of participatory negotiations. This oversight has received greater attention, and a recent research project addresses the need for participation and political representation of the Palestinians in the Occupied Territories and in the diaspora. ${ }^{43}$

\section{Challenges for UNRWA and the registered refugees}

During the last mandate of Commissioner-General Peter Hansen and following the Geneva conference recommendations of June $2004,{ }^{44}$ UNRWA implemented several important reforms. ${ }^{45}$ The Organizational Development Process has contributed to management transformations, with a particular focus on decentralization, accountability, efficiency, and efficacy in the implementation of strategic objectives. In parallel, new forms of evaluation and knowledge management have been adopted with the aim of improving data gathering to better support planning processes. ${ }^{46}$

While underlying its role in advocating and providing for the development and humanitarian needs of the Palestinian refugees, and expressing the will of strengthening partnership and increasing participation, in the forward to the new "Medium Term Strategy for 2010-15", the Commissioner-General Karen Abu Zayd has reaffirmed "[the Agency's] commitment to meeting the human development aspirations of refugees, with particular emphasis on the most vulnerable [...] the principal instruments will remain its programs of basic education, primary health care, social safety-net, infrastructure improvement and microfinance". 47

Three main challenges seem to be key areas of interaction not only between UNRWA and the Palestinian refugees but also of primary concern for host and donor countries and for multilateral and bilateral cooperation agencies.

\subsection{Education}

As outlined above, education historically became the main sector of UNRWA activity, both in terms of funds allocated and personnel involved. As a form of non-political human development (and in contrast to the work programmes of the 1950s), education has been a major operational compromise. On top of that,

43 See Karma Nabulsi, Palestinian Registers: Laying Foundations and Setting Directions. Report of the Civitas Project, Oxford, Nuffield College, 2006.

44 On 7-8 June, 2004, under the auspices of the Swiss government UNRWA organized in Geneva a conference titled "Meeting the Humanitarian Needs of Palestine Refugees in the Near East: Building partnership in support of UNRWA". The conference gathered up to 120 international donor countries and largely contributed to setting the agenda for the Agency's 2005-2009 Medium Term Plan (http://www.un.org/unrwa/ genevaconference/select.html) (last visited 17th September 2009).

45 See UNRWA, Medium Term Plan 2005-2009, Public Information Office, UNRWA Headquarters.

46 See the contribution of $\mathrm{R}$. Terbeck in this volume.

47 UNRWA, Medium Term Strategy 2010-2015, Public Information Office, UNRWA Headquarters. 
a young population constitutes most beneficiaries of UNRWA's assistance: 50 per cent of the registered refugees are below 25 years of age. ${ }^{48}$

The schooling provided by UNRWA has been largely constructed on a Western, secular, liberal model, instituted to produce well-socialized, compliant future subject-citizens for a modern state. The Agency is not a State, however; rather, it acts on behalf of the United Nations, operates in host countries and receives funding from international donors. It is both an insider and an outsider, staffed at the local level by refugees and managed at the highest levels by international staff. The practice of teachers is embedded in their local experience: they themselves are refugees and share the same experiences of most pupils' parents. Once again, as a service provider for education, UNRWA faces a peculiar situation since a plurality of actors is involved in shaping the schooling of refugee children.

In relation to its educational content, the UNRWA system was set up in coordination with the UNESCO and structured around the curricula adopted by host countries. The elementary programmes, for example, are rather close to a Western-style, secular education and a continuation of the Turkish and British state schools of pre-1948 Palestine, although with better resources and extended to a wider public. Control over the educational curricula of UNRWA's schools has been a key issue for host countries and for Israel in the Occupied Territories. In the heyday of nationalist propaganda, UNRWA schools were targeted by the PLO as a place to instil a national tradition in refugee children. In this sense, UNRWA has been often under pressure since mass public schooling is largely a process of nation-building and tends to inspire loyalty to an existing system of state authority.

While the PA has already begun to build its own educational system, it could be important to reconsider the centrality of UNRWA schools in the framework of a future resumption of the peace process. With due respect to the national curricula of host countries, UNRWA schools could do more to foster a culture of peace and reconciliation.

For years, UNRWA schools were well reputed, on the basis of the high quality services it provided. In the past decade, however, the situation has been deteriorating. Due to a shortage of buildings, most UNRWA schools operate on a double shift basis both for children and teachers, classrooms are overcrowded, and the means to renovate buildings and furniture are unavailable. Furthermore, teachers lack employment security with most new teachers receiving only one-year contracts. The situation, which is partly a by-product of the Agency's financial crisis, can have serious consequences.

First, education no longer seems to offer redemption in political terms. Partly because the Oslo Process has left refugees in limbo until final status negotiations are reached, the widespread Palestinian nationalist fervour among UNRWA teachers from the 1960 s to the 1980 s has been progressively fading

48 See the contribution of D. Chatty in this volume on refugee youth. 
away and, in many cases, even silenced. Schools and youth clubs in refugee camps have often been the target of Islamist activists. In the West Bank and Gaza, moreover, the Intifada al-Aqsa has damaged the infrastructure and seriously disrupted the annual school calendars for most pupils.

Second, education has not only helped forge national consciousness; it has also helped the formation of a professional middle class in Palestine and in the region. Estimates for the 1960s and 1970s indicate that almost one-third of the male labour force in Palestine was working in the Gulf. This was tremendously important for improving living standards under occupation and in the refugee camps. Today, however, education no longer seems to aid in social and economic development as the local and regional labour markets no longer offer the opportunities as were offered in the 1960s, 1970s, and even 1980s. Many now question the value of investing in years of education. Fed by a poor local labour market, emigration tends to become an imagined outlet with success stories of family members abroad who "made it" despite not being formally educated. Therefore, there is a strong need to adapt education to the changing economic situation at the beginning of this new century. ${ }^{49}$

\subsection{Development}

A vision of development, now outdated, is inscribed in the very acronym of the Agency. The "W" of UNRWA, which stands for "works", refers to the large- and small-scale development projects, mainly in agriculture, that the Agency was mandated to implement in the 1950s. The development approach of the time was backed by a modernist ideology where, among others, the objectives of economic growth were sustained by the belief that economic progress was conducive to social and political stability. The project of transferring the experience of the Tennessee Valley Authority to the Near East was very much appealing to Western donors. Presented as technical, it was opposed locally due to its political consequences. Though development approaches have become more sophisticated with time, most international donors consider the equation between economic growth and political stability a key to a successful peace process.

In the late 1950s, UNRWA abandoned its works programmes but, from the early 1960 s to the late 1980 s, it maintained and developed an approach of relief and social welfare. The Agency coordinated its endeavours with the technical assistance of UNESCO and the World Health Organization (WHO) for the education and health programmes, but evaded the debate with other United Nations Agencies on development policies and strategies. Within a context of social welfare, UNRWA has shown a significant capacity to deliver high-level services in health care and education. Though not necessarily motivated by competition with those of the host countries, UNRWA services have been viewed as having a better reputation for a long period of time.

49 See the contribution of M. Rosenfeld in this volume. 
Paradoxically, the "routinization" of UNRWA's welfare activities, combined with the economic realities of the situation of long-term refugees, has often produced a de facto resettlement/rehabilitation/reintegration process. This is true for many refugees in Jordan, Syria, the West Bank, and Gaza. While many may face discrimination, lack a sense of local identity, or feel existentially estranged, most have found an economic space in the countries where they live. ${ }^{50}$

The kind of vocational training provided by UNRWA has corresponded to the demand of the Gulf labour market. Likewise, starting from the mid-1980s, the kind of training the Agency provided was no more competitive (for skilled and semi-skilled labourers) than cheaper Asian labour force. Vocational training did not seem anymore appropriate for self-employment in economies dominated by small and micro-enterprises.

By the late 1980s, with the beginning of the first Intifada, UNRWA reintroduced development planning in new ways through the Expanded Programme of Assistance (EPA) and the Extraordinary Measures for Lebanon and the Occupied Territories (EMIOT), mainly consisting of new infrastructure projects and income-generating activities for alleviating poverty. The Peace Implementation Program (PIP), set up in 1994 in the wake of the beginning of the peace process, was of a similar nature. Concentrating 90 per cent of its resources in the West Bank and Gaza, it was mainly focused on school construction and repair, camp infrastructure improvement, and loans to improve refugee self-sufficiency. This gave UNRWA a role in economic development for Palestinian refugees.

Starting in the mid-1980s, development programmes have gained greater acceptance by the refugees (in the West Bank and Gaza in particular) and are not necessarily perceived as a direct threat to the implementation of the right of return. A clear distinction between socio-economic rehabilitation ( $\left.t a{ }^{\prime} h \hat{\imath} l\right)$ and resettlement (tawtîn) has developed within these refugee communities. This attitude has been officially backed by the PLO. While this distinction is recognized in Jordan, however, refugee communities seem less convinced that donor countries make this distinction in their economic approach to a peace process.

Finally, it is important to note that UNRWA has altered its approach to development as well as its ideologies repeatedly over the past sixty years. From "top-down" modernist approaches implemented in the 1950s (through the works programmes in agricultural development), to "human development" objectives in the 1960s and 1970s realized through education and from social and participatory approaches in the 1980s (integrating human rights principles during the Intifada), to the objective of "empowering refugees" (through income-generating projects, micro-finance and micro-credit programmes), the history of UNRWA is a full story of relief, humanitarian, and development experiences. $^{51}$

50 See the contributions of Jalal al-Husseini and R. Bocco in this volume.

51 See the contribution of T. Rempel in this volume. 


\subsection{Camps, demography, and urban planning}

UNRWA provides services to ten camps in Jordan, nineteen in the West Bank and eight in the Gaza Strip, twelve in Lebanon, and nine in Syria. Most camps are close to major towns or have become part of them. Though the size and the number of residents in camps may vary from a few thousand people to almost 100,000 , most refugee camps are characterized by a high population density. Furthermore, it is not unusual to find among camp dwellers non-registered refugees (be they Palestinians or nationals of other countries) who have similarly poor living standards.

Historically, the number of people who have been living in camps has been about 25-30 per cent of the total number of Palestinian registered refugees, the most notable exception being in Gaza and Lebanon. The contemporary location or topography of camps does not correspond necessarily to the original ones. In fact, many camps built unofficially after 1948 were abandoned and others were created. Due to the 1967 war, some camps were abandoned and new emergency camps were set up.

Sociologically, they often resemble urban neighbourhoods or rural villages that have transformed into small towns, and they show dynamics typical of urban relationships. Not all camp dwellers or their descendants have been living in the camps since their creation. Because leaving the camps has never entailed a loss of refugee status, mobility between the inside of the camps and the communities outside them has always been prevalent. This means that, for over four generations of registered refugees, the experience of living in a camp has been shared by far more people than the average officially recognized figure of camp residents would suggest. The personal narratives and popular memory of refugees are not only a reservoir for oral history; they also allow social change to be traced and the related perceptions among refugees to be analysed. Multiple links - of social and economic nature - exist between camp refugees and their immediate environment, given the porous camp borders. The role of the camp in the imagery of Palestinian nationalism has brought them politically centre-stage.

Like UNRWA, in principle, the camps have been considered "temporary". Symbolically, they represent the plight of the Palestinian people and their rights. Refugees do not own land in the camps, but they can use it under the supervision of UNRWA. Refugees are generally owners of the houses they built on camp land. In general, a camp is a piece of land given by the host country, to host refugees who can build upon it after receiving written authorization from UNRWA. But, in many cases (in Jordan, Lebanon, and the West Bank in particular), original camp land was also privately owned. Ten years after the 1948 war, huts replaced tents in the camps. The structure of public spaces was often altered, invaded by housing units, generally in response to overcrowding. Population density has also contributed to shape or reshape the settings of private and public spaces and social interactions. ${ }^{52}$

52 See the contribution of $\mathrm{H}$. Rueff and A. Viaro in this volume. 
For a number of donor countries, the future vision of refugee camps located in urban contexts has been that of poor urban neighbourhoods where economic aid needed to target the improvement of living standards. ${ }^{53}$ Due to overcrowding, it is not unusual that the refugees demand that UNRWA rent additional land in order to expand camp borders without endangering their right of return. In the West Bank, for example, the Camp Councils elected during the spring of 1997 were mandated by the refugee population to work both for their right of return and to improve living conditions in camps.

The legal and political settlement of the camp question has been another part of the peace negotiations in the Oslo years, certainly a more internal one for the PA and the host countries' governments but nonetheless a crucial one for the socio-economic future of the camp dwellers. From the early 2000s and with increased funding from international donors, the camps' rehabilitation issue has been reintroduced into the Palestinian internal debate and accelerated in the past few years. This development partly followed the Geneva conference of 2004, since when international donors (the European Union in particular) have advocated for programmes on camp infrastructure improvement to be relaunched. ${ }^{54}$

\section{Research perspectives on the refugees and the peace negotiations}

Two main research trends in social sciences which have been developing in the past decade are necessary to better grasp the evolving socio-economic situation of the Palestinian refugees and to rethink the past while building on both Israeli and Palestinian perspectives on ending the conflict.

\subsection{The sociology of return}

UNRWA is expected to have an intimate knowledge of its beneficiaries and to provide its services uniformly throughout its geographical fields of operation, while constantly taking into account the conditions of each field. The Palestinian refugees constitute a collective group from UNRWA's administrative perspective but, from a sociological point of view, fifty years of exile and three generations of refugees have engendered different experiences of "refugee-ness", different attitudes of adaptation to changing political contexts and economic opportunities. The pace of change has even accelerated in the post-Cold War era, with the effects of what has been labelled globalization in terms of new logics of economic networks, mobility, and communication patterns.

53 The European Union had already begun to use this terminology at the beginning of the Oslo Process. See European Commission Shepherd of the Social and Economic Infrastructure Development Theme, Report to the Refugee Working Group of the Middle East Peace Process ("Bristol Report"), Oxford, Office for International Policy Services and Refugee Studies Centre, 1994.

54 See the contribution of S. Hanafi and Ph. Misselwitz in this volume. 
The Palestinian refugee question has generally been framed by juridical perspectives and political debates around the possible policy options for peacebuilding scenarios. Through international comparisons, the juridical studies have helped put the Palestinian case in perspective but have often discarded or overlooked the sociological, local, and transnational evolving reality of the refugees. As recent anthropological studies on Afghani ${ }^{55}$ and Iraqi ${ }^{56}$ migrants and refugees have shown, there is a need to re-conceptualize the vision of forced migration and its classical juridical solutions. By taking into account the socio-economic transnational networks of (forced) migrants, their resilience and their capacity to adapt to new environments, different strategies of mobility have become the rule rather than the exception.

The specificities and potential role of the Palestinian diaspora were already the object of some studies in the $1990 \mathrm{~s}^{57}$ and have attracted the attention of a number of researchers more recently. ${ }^{58}$ However, while Palestinian migrants and refugees have largely enjoyed mobility in the Middle East and outside the region, their circulation in historic Palestine has been limited or prevented by Israel inside its own borders and in the occupied territories of the West Bank and Gaza.

Though, in this sense, parallels between the Palestinian case on the one side and the Afghani and Iraqi case on the other side are limited, other studies conducted in the past decade 59 show how Palestinian refugees in the diaspora have been rethinking their relationships to the original homeland, how new discourses and practices of nation and territory, and new symbolic meanings attached to the right of return in particular have emerged. ${ }^{60}$

55 A. Monsutti, "Afghan Migratory Strategies and the Three Solutions to the Refugee Problem", Refugee Survey Quarterly 27(1), 2008, 58-73; and "Itinérances transnationales: un éclairage sur les réseaux migratoires afghans", Critique Internationale no. 44, 2009, 83-104.

56 G. Chatelard, "Un système en reconfiguration. L'émigration des Irakiens de la guerre du Golfe à la guerre d'Irak (1990-2003)", in H. Jaber et F. Métral (dir.), Mondes en mouvements. Migrants et migrations au MoyenOrient au tournant du XXIème siècle, Beyrouth, Ifpo, 2005, 113-55 ; and G. Chatelard \& K. Doraï, "La présence irakienne en Syrie et en Jordanie. Dynamiques sociales et spatiales, et modes de gestion par les pays d'accueil", Maghreb-Machrek, no. 199, 2009, 43-60.

57 See Sari Hanafi, Entre deux mondes: les hommes d'affaires palestiniens de la diaspora et la construction de l'entité palestinienne, Le Caire, CEDEJ, 1997; and Are Hovdenak, Jon Pedersen, Dag H. Tuastad \& Elia Zureik, Constructing Order: Palestinian Adaptations to Refugee Life, Oslo, FAFO, Report No. 236, 1997.

58 See Julie Peteet, "Problematizing a Palestinian Diaspora”, International Journal of Middle East Studies, vol 39, 2007, 627-46; Helena Lindholm-Schulz. The Palestinian Diaspora. Formation of Identities and Politics of Homeland, London, Routledge, 2003; and K. Nabulsi, op. cit.

59 S. Hanafi, "The Sociology of Return: Palestinian Social Capital, Transnational Kinship and the Refugee Repatriation Process", in E. Benvenisti, Ch. Gans, S. Hanafi (eds.), Israel and the Palestinian Refugees, Berlin, Springer, 2007; and S. Hanafi (ed.), Crossing Borders, Shifting Boundaries, Cairo, The American University in Cairo Press, Cairo Papers in Social Science, 29(1), 2008.

60 See J. Al-Husseini and A. Signoles, "Construction nationale, territorialité et diasporisation: le cas palestinien", Maghreb-Machrek, no. 199, 2009, 23-42; S. Hanafi, "La diaspora palestinienne à l'heure de l'Intifada. Droit au retour et logiques de réseaux", in A. Dieckhoff and R. Leveau (eds.), Israéliens et Palestiniens: la guerre en partage, Paris, Balland, 2003, 259-81. 


\subsection{Dealing with the past}

As asked in the title of a recent contribution ${ }^{61}$ on the Palestinian refugee issue negotiations: should dealing with the past be the prelude for reaching durable peace agreements?

During the past ten years a number of works have tried, in a policy perspective or in a more fundamental research approach, to look at the internal dynamics of both Palestinian and Israeli societies, sometimes in a comparative perspective, concerning the big questions of exile and return, equity and peace, as perceived by local and international actors. ${ }^{62}$

Among the strategies of conflict resolution that developed in the 1980s and the 1990s, the transitional justice approaches, through the development of different forms of Truth and Reconciliation Commissions (drawing in particular from the Latin American and South-African experiences) have had interesting impacts and applications worldwide. Though the Middle East in general has seemed immune from such experiences, ${ }^{63}$ one should not underestimate the impact of various initiatives conducted in Israel and Palestine during the past fifteen years, sometimes initiated under the auspices of the "People to People" projects of the Oslo process. Most of these initiatives, and the studies elaborated on them, not only consider that the role of education should be central in shaping new attitudes to the "other" and therefore essential for building peace, ${ }^{64}$ but that the refugee issue is also and most often at the core of the debates and of the projects, ${ }^{65}$ which explore the potential of grassroot approaches.

The two research trends briefly sketched above point to the centrality of (refugee) societies' analysis not only for understanding changes at the local, national, and international levels but also for rethinking policy options and

61 See Rex Brynen, The Past as Prelude? Negotiating the Palestinian Refugee Issue, London, Chatham House, Briefing Paper MEP/PR BP 08/01, June 2008.

62 In chronological order, it seems worthwhile to mention J. Ginat and B. Perkins (eds.), The Palestinian Refugees: Old Problems, New Solutions, Brighton, Sussex Academic Press, 2001; A. M. Lesch and I. S. Lustick (eds.), Exile and Return: Predicaments of Palestinian and Jews, Philadelphia, PA, University of Pennsylvania Press, 2005; M. Dumper (ed.), Palestinian Refugee Repatriation: Global Perspectives, London, Routledge, 2006; R. Brynen and R. Rifa'i (eds.), The Absorption of Palestinian Refugees, London, I. B. Tauris, 2006; M. Dumper, The future for Palestinian Refugees. Toward Equity and Peace, Boulder, Lynne Rienner, 2007; E. Benvenisti, Ch. Gans, S. Hanafi (eds.), Israel and the Palestinian Refugees, Berlin, Springer, 2007.

63 Morocco and its 'Equity and Conciliation Commission' set up after the accession to the throne by Mohammad VI seems to be quite an exception in the Arab world. In the Algerian case, the Reconciliation Law promulgated by President Bouteflika seems to be a rather "imposed" policy of reconciliation.

64 See for example D. S. Halpérin (ed.), To live together: Shaping New Attitudes to Peace through Education. Paris and Geneva, UNESCO and IBE, 1997; S. Adwan and D. Bar-On, Histoire de l'Autre, Paris, Liana Levi \& Bethlehem, Peace Research Institute in the Middle East, 2003.

65 J. Hilal and I. Pappé (eds.), Parlare con il nemico. Narrazioni palestinesi e israeliane a confronto, Torino, Bollati Boringhieri, 2003; D. E. Zammit, H. al Treiki and I. Pappé (eds.), Human Rights and the Forgotten Histories of the Israeli-Palestinian Conflict, special issue of the Mediterranean Journal of Human Rights, vol. 8, no. 2, 2004; E. Kaufman, W. Salem and J. Verhoeven (eds.), Bridging the Divide: Peacebuilding in the Israeli-Palestinian Conflict, Boulder, Lynne Rienner, 2006; P. Scham, W. Salem and B. Pogrund (eds.), Shared Histories: A Palestinian-Israeli Dialogue, Walnut Creek (USA), Left Coast Press, 2005; R. Rotberg (ed.), Israeli and Palestinian Narratives of Conflict: History's Double Helix, Bloomington, Indiana University Press, 2006; R. Dudai, "A model for Dealing with the Past in the Israeli-Palestinian Context", The International Journal of Transitional Justice, 1, 2007, 249-67. 
peace scenarios. During the last two decades, many decision-makers have paid lip service to the jargon of participation but most often have disregarded the local actors, whose support could have actually made the difference for the success in the implementation of many programmes. In this sense, the Palestinian refugees, and more largely the Israeli and Palestinian societies, with their hopes and dreams for peace and justice seem to have been betrayed by their own political representatives.

As time goes by, finding a solution to the Israeli-Palestinian conflict seems to be increasingly difficult, insofar as both partners to a possible peace seem to be ever more entrenched in their self-perceptions as victims. Although the Holocaust and the Nakba cannot be compared in terms of intentions of the perpetrators and in terms of effects on the victims (the genocide in particular), both events have played a crucial role in shaping the Jewish-Israeli and the Palestinian collective identities in the twentieth century.

Yet solving one of the oldest Middle East conflicts could be a real blow against the enemies of peace in both camps, against those actors and movements who have been advocating violence as the mean to assert their rights. Peace will have its own risks too in the region, and could be a destabilizing factor for those authoritarian regimes that have been manipulating the Palestinian cause to justify repressive policies at home. It could be destabilizing also for Israel, whose population has been accustomed to uniting against a common threat from the outside. It is important to consider how the role of the Israeli Defense Forces, their social, national, and economic role in the advent of peace should be considered $^{66}$ and how the past can be examined as well. Should social amnesia and juridical amnesty prevail to confront what Israelis and Palestinians have done to one another? Durable peace requires a number of hard compromises - on the refugees' right of return, among others - but such compromises cannot simply be imposed. Beyond the role played by international law and external stakeholders, the most serious guarantees for a peacebuilding process and for a long-lasting legitimacy of the Israeli State and its future Palestinian counterpart can likely only be given by their societies, made participative actors in the negotiations about their fate.

Finally, as a number of contributions in this volume show, the critical role of researchers and intellectuals may continue to play a modest but fundamental role in deconstructing the walls of misunderstanding, the 'red lines' and the taboos laid in negotiations by public opinions and political decision-makers. As William Ossipow correctly points out in a recent essay, understanding means trying to reconstruct the history, grasping the relationship with the 'other', and exploring and analysing the context of the interface with the other. Understanding also means recognizing the complexity and ambiguity of each situation, as they are inherently hybrid. ${ }^{67}$

\footnotetext{
66 See Baruch Kimmerling, The Invention and Decline of Israeliness, State, Society and the Military, Berkeley, University of California Press, 2001.

67 See William Ossipow (ed.), Israël et l'Autre, Genève, Editions Labor \& Fides, 2005, 10-2.
} 